\title{
Nematode infestation and $\mathrm{N}$-effect of legumes on soil and crop yields in legume-sorghum rotations
}

\author{
Vincent Bado ${ }^{1 *}$, Abdoulsalam Sawadogo ${ }^{2}$, Bouma Thio ${ }^{2}$, André Bationo $^{3}$, Karim Traoré ${ }^{2}$, \\ Michel Cescas ${ }^{4}$

\footnotetext{
${ }^{1}$ Africa Rice Center (AfricaRice), Sahel Regional Station , Saint Louis, Senegal; *Corresponding Author: V.Bado@cgiar.org

${ }^{2}$ Institut de l'Environnement et de Recherches Agricoles, Bobo-Dioulasso, Burkina Faso;

${ }^{3}$ The Tropical Soil Biology and Fertility Institute of International Center for Tropical Agriculture, Nairobi, Kenya;

${ }^{4}$ Département des Sols et Génie Agroalimentaire (FSSA), Université Laval Ste Foy Québec, Québec, Canada.
}

Received 28 June 2010; revised 24 March 2011; accepted 31 March 2011.

\section{ABSTRACT}

The effects of cowpea (Vignaunguiculata) and groundnut (Arachis hypogea) on succeeding sorghum yields, soil mineral $\mathrm{N}$ and nematode infestation were studied during five cropping seasons (2000 to 2004) in a weakly acid Ultisol of the agronomy research station of Farakô-Balocated in the Guinean zone of Burkina Faso, West Africa. A factorial $5 \times 5$ design of five crop rotations with five fertilizer treatments in a split-plot arrangement with four replications was used. Sorghum yields were affected by the two factors (rotation with legumes and fertilizer applications) during the four years. But interactions were not observed between the two factors. Monocropping of sorghum produced the lowest yields and legume-sorghum rotations increased sorghum yields by $50 \%$ to $300 \%$. Groundnut-sorghum and cowpea-sorghum rotations increased soil mineral $\mathrm{N}$ by $36 \%$ and $52 \%$, respectively. Crop rotation influenced nematode infestation but the effects on soil and sorghum root infestation differed according to the rotation. The cowpeasorghum rotation increased soil and sorghum root infestationby nematodes while groundnut-sorghum decreesed the nematode population. The soil of the cowpea-sorghum rotation contained 1.5 to 2 times more nematodes than the soil of the monocropping of sorghum. In contrast, the soil of the groundnut-sorghum rotation contained from 17 to 19 times fewer nematodes than that of themonocropping of sorghum. However, nematode infestation did not affect any of the succeeding sorghum yields. It was concluded that the parasitic effect of nematodes was limited by the predominance of positive $\mathrm{N}$-effects on the development of succeeding sorghum.

Keywords: Legume; Nematode; Nitrogen; Crop Rotation; Sorghum

\section{INTRODUCTION}

In sub-Saharan Africa, crop yields are limited by many factors such as nutrient deficiencies. Soils have inherently low levels of nutrients because of low soil organic matter levels and limited use of nutrient inputs by farmers. Nitrogen $(\mathrm{N})$ and phosphorous $(\mathrm{P})$ deficiencies are the main soil fertility constraints in most of the soils of West Africa [1]. Chemical fertilizers are imported from developed countries and remain expensive for poor small holders who therefore never use them or only occasionally apply small quantities. While 73 $\mathrm{kg} \cdot \mathrm{ha}^{-1}$ of chemical fertilizers are used by farmers in Asia, only $8 \mathrm{~kg} \cdot \mathrm{ha}^{-1}$ are used in Africa [2]. $\mathrm{N}_{2}$-fixing legume crops can help improving soil fertility as sources of nitrogen. Some legume crops such as groundnut (Arachis hypogea L.) and cowpea (Vignaunguiculata (L.) Walp) are traditionally cultivated by farmers in rotation or intercropping with cereals. Legume crops can supply $\mathrm{N}$ for non-fixing cereals via biological nitrogen fixation. In cropping systems, $\mathrm{N}_{2}$-fixing legumes can supply $\mathrm{N}$ to the subsequent crops through fallen senescent leaves and below ground parts, leading to an increase in succeeding crop yield [3-5]. However, the improvement of soil N content by legumes also creates favourable conditions for the development of soil fauna such as parasitic nematodes that could affect the succeeding crop. Some legumes such as groundnut can reduce the population of nematodes, while other legumes can increase nematode infections [3]. In legume-cereal rotations, we can hypothesize that a high population of parasitic nematodes induced by a previous legume could probably reduce the 
development, $\mathrm{N}$ absorption (or N-effect) and the yields of the succeeding crop. Conversely, legumes that can reduce nematode infestation such as groundnut should probably have a better N-effect on the succeeding crop. Little research has been oriented on the interaction of $\mathrm{N}$-effect and nematode induced by legumes on soil and succeeding crop. This research aimed to study the combined effect of the two factors ( $\mathrm{N}$ and nematode infestation) on soil and succeeding crop.

\section{MATERIALS AND METHODS}

The study was undertaken through field experiments carried out over five years (2000-2004) at the agronomic research station of Farakô-Ba $\left(4^{\circ} 20^{\prime}\right.$ West, $11^{\circ} 6^{\prime}$ North and $405 \mathrm{~m}$ altitude), located in the Guinean savannah zone of Burkina Faso. This agro ecological zone has one rainy season per year, starting in May-June and ending in October. During the five cropping seasons of the experiment, annual rainfall during the cropping seasons varied from $1058 \mathrm{~mm}$ in year 2000 to $639 \mathrm{~mm}$ in year 2002 (Table 1). In general, planting dates occurred in June and harvesting was carried out in October. The experiment was laid down on a six-year-old fallow area on an Ultisol, a weakly acid (pH/KCl: 5.6$)$ sandy soil (74\%) with low clay $(7 \%)$ and organic carbon $(0.6 \%)$ contents. Available P (P-Bray I: $5.6 \mathrm{mg} \cdot \mathrm{kg}^{-1}$ ), Ca, $\mathrm{Mg}$ and exchangeable $\mathrm{K}$ and exchange capacity (ECEC: $1.8 \mathrm{coml}$. $+\mathrm{kg}^{-1}$ soil) were very low.

Two legume crops: groundnut (Arachis hypogea L.) and cowpea (Vignaunguiculata (L) Walp) were used. Improved varieties of groundnut (RMP-12) and cowpea (KVX-61-1) recommended by the national agronomic research institute (INERA) for the Guinean savannah zone were sown with, respectively, planting densities of 62,500 and 125,000 plants per hectare. An improved variety of sorghum (Sariaso) with a planting density of 62,500 plants per hectare was used.

A factorial $5 \times 5$ experiment in a split-plot experimental design with randomised block arrangement and four replications was used. The five crop rotations (Table 2) were used as first factor in the main plots. Each main plot was split intofive sub plots for different fertilization treatments (PK, NPK, NPK + Dolomite, NPK + Manure and Control) employed as second factor. Chemical fertilizers were applied at rates of $14 \mathrm{~kg} \mathrm{~N} \mathrm{ha}^{-1}$, $10 \mathrm{~kg} \mathrm{P} \mathrm{ha}^{-1}$ and $11 \mathrm{~kg} \mathrm{~K} \mathrm{ha}^{-1}$ to the two legumes using complex NPK fertilizer, triple super phosphate and potassium chloride. For the manure-containing treatments, three tonnes per hectare of air-dried cattle manure were applied. Cattle manure contained 1.8\%, 18.40\%, 0.31\% and $0.16 \%$, respectively, of $\mathrm{N}, \mathrm{C}, \mathrm{P}$ and $\mathrm{K}$. In the dolomite-containing treatments, one tonne $\mathrm{ha}^{-1}$ of dolomite (249 $\mathrm{kg} \mathrm{ha}^{-1}$ of Ca and $114 \mathrm{~kg} \mathrm{ha}^{-1}$ of Mg) were used.

Except for urea, all fertilizers were applied at sowing. Nitrogen fertilizers were split on sorghum plots: $14 \mathrm{~kg}$ $\mathrm{N}^{-1}$ with NPK fertiliser at sowing and $23 \mathrm{~kg} \mathrm{~N} \mathrm{ha}^{-1} 40$ days after sowing (DAS). Legumes were not inoculated. As regards farmer's traditional practices, the residues of

Table 1. Monthly and annual rainfall at Farakô-Ba during the five years of the experiment.

\begin{tabular}{cccccccc}
\hline & \multicolumn{7}{c}{ Months } \\
\cline { 2 - 6 } Years & May & June & July & August & September & October & Total \\
2000 & 60 & 172 & 236 & 309 & 241 & 41 & 1059 \\
2001 & 66 & 80 & 154 & 229 & 153 & 33 & 715 \\
2002 & 58 & 65 & 184 & 175 & 125 & 32 & 639 \\
2003 & 98 & 113 & 98 & 244 & 243 & 43 & 839 \\
2004 & 152 & 161 & 178 & 344 & 268 & 98 & 1201 \\
Mean & 87 & 118 & 170 & 260 & 206 & 49 & \\
\hline
\end{tabular}

Table 2. Rotation of the three crops of the six treatments during the five years (2000-2004) of experimentation.

\begin{tabular}{cccccc}
\hline & \multicolumn{5}{c}{ Years } \\
\hline Crop rotations & 2000 & 2001 & 2002 & 2003 & 2004 \\
Cowpea-sorghum & Cowpea & Sorghum & Cowpea & Sorghum & Cowpea \\
Sorghum-cowpea & Sorghum & Cowpea & Sorghum & Cowpea & Sorghum \\
Groundnut-sorghum & Groundnut & Sorghum & Groundnut & Sorghum & Groundnut \\
Sorghum-groundnut & Sorghum & Groundnut & Sorghum & Groundnut & Sorghum \\
Sorghum-sorghum & Sorghum & Sorghum & Sorghum & Sorghum & Sorghum \\
\hline
\end{tabular}


sorghum and legumes are exported at the end of each season. Only the senescent leaves and residues of roots of the below ground parts remain as a source of organic residues recycled in the soil.

The N-effects of legumes were evaluated by soil $\mathrm{N}$ mineralization $\left(\mathrm{NH}_{4}^{+}+\mathrm{NO}_{3}^{-}\right)$during the first two months of the second cropping season (2001) after one season of rotation. Soil samples were taken in the first $20 \mathrm{~cm}$ layer at sowing, 9, 20, 30, 40 and 53 days after sowing. All sub-plots of the five fertilizer treatments were sampled. Soil samples were taken in sorghum plots of three rotations (sorghum-sorghum, cowpeasorghum and groundnut-sorghum). Mineral N was extracted with $1 \mathrm{M} \mathrm{KCl}$ solution and measured by the colorimetric method [6].

Nematode populations were assessed during the cropping season of 2001. All sub-plots of the five fertilizer treatments were sampled. Soil samples were taken in sorghum plots of the three rotations (sorghum-sorghum, cowpea-sorghum and groundnut-sorghum). Soil and root samples of sorghum were removed at 30 and 90 days after sowing, and nematodes were extracted and measured using the methodology described by Seinhorst [7]. Many zero values and high coefficient of variation were observed, particularly on sorghum root infestation by nematodes. Thus, logarithmic function Eq.1 was used for data transformation before statistic analysis [8].

$$
\mathrm{y}=\log \mathrm{x}+1
$$

$\mathrm{x}$ was the number of nematodes and $\mathrm{y}$ the transformed value.

Agronomic data of sorghum yields were first analyzed per year using the Fisher test for comparison of treatment effects [8]. Then, the global effects of the four years were analyzed using the year as a factor. The rotations and fertilizers were used as first and second factors, respectively.

\section{RESULTS AND DISCUSSIONS}

\subsection{Nematode Infestation}

The effects of crop rotations on soil and sorghum roots infestation by nematodes are presented on (Table 3). Fourgroups of nematodes (Pratylenchus, Scutellonema, Helycotylenchus and Trychodorus) were identified in the soil. The two most important groups identified in the soil were Helicotylenchus (55\%) and Scutelonema (34\%). But only two groups (Pratylenchus and Scutelloma) were identified on sorghum roots. However, sorghum roots were mainly infested by Pratylenchus (80\%) and Scutelonema (20\%) at 30 days after sowing and by Pratylenchusonly at 90 days after sowing. But soil and roots infestation by nematodes was not affected by fertilizer application (data not shown). Only crop rotation affected soil and roots infestation $(\mathrm{p}<0.01)$ by nematodes and interactions were not observed between these two factors. Otherwise, variation in the populations of nematodes was due to crop rotations.

Groundnut and cowpea had opposite effects in the soil and on the succeeding sorghum root infestation by nematodes. Compared to the groundnut-sorghum rotation, a cowpea-sorghum rotationincreased soil $(\mathrm{p}<0.01)$ and sorghum roots $(p<0.01)$ infestationby the three groups of nematodes (Pratylenchus, Scutellonema, Helycotylenchus). The soil of the cowpea-sorghum rotation contained 1.5 to 2 times more nematodes than the soil used formono cropping of sorghum. As for cowpea-sorghum rotation, the monocropping of sorghum also increased the population of Pratylenchus and Scutellonemain the soil and differences were not observed between the two rotations. On the other hand, groundnut decreased the incidence of the four nematodes in the soil. In groundnut-sorghum rotations, the soil contained from 17 to 19 times fewer nematodes than cowpea-sorghum and Môn croppedsorghum.

\subsection{Soil Mineral Nitrogen}

For all rotation treatments, soil mineral $\mathrm{N}$ decreased rapidly during the season (Figure 1). The first rains of the season induced a resurgence of microbial activity leading to a "mineralization flush" of soil organic nitrogen and increases in mineral $\mathrm{N}$. The mineral $\mathrm{N}$ decline can be explained by the decrease of the mineralization of soil organic residues, by $\mathrm{N}$ uptake by plants, $\mathrm{N}$ leaching and other losses of $\mathrm{N}$. The mineralization of soil organic residues started with the first rains of the season and decreased over time, as indicated by mineral $\mathrm{N}$ decreases.

Throughout the season, fertilizer applications did not affect soil mineral $\mathrm{N}$. However, soil mineral $\mathrm{N}$ was affected ( $p<0.05$ ) by crop rotation at the start of season $(1$ 20 days after sowing) and no interaction was observed between fertilizer and rotation. During this first period (1 20 days after sowing), the presence of legumes in the cropping systems increased soil mineral $N(p<0.05)$ and differences were not observed between the two legumes (Figure 1). At sowing, soil mineral $\mathrm{N}$ varied from $42 \mathrm{~kg} \mathrm{~N}$ $\mathrm{ha}^{-1}$ in monocropping of sorghum to 55 and $62 \mathrm{~kg} \mathrm{~N} \mathrm{ha}^{-1}$ when sorghum was rotated with groundnut and cowpea, respectively. Otherwise, groundnut-sorghum and cowpea-sorghum rotations increased soil mineral N from 36\% and $52 \%$, respectively.

\subsection{Sorghum Yields}

During the first season (absence of rotation effect), only the effects of fertilizers were measured. The effects 
Table 3. Effects of crop rotation with legumes (groundnut-sorghum, cowpea-sorghum) and monocropping of sorghum on soil (nematodes/dm3 of soil) and sorghum roots (nematodes/g) infestationby nematodes at 30 and 90 days after sowing in 2001.

\begin{tabular}{|c|c|c|c|c|c|c|c|}
\hline & \multirow[b]{2}{*}{ Daysaftersowing } & \multirow[b]{2}{*}{ Croprotations } & \multicolumn{5}{|c|}{ Nématodes } \\
\hline \multirow{7}{*}{$\begin{array}{l}\text { Nematodes in } \\
\text { the soil }\end{array}$} & & & Pratylenchus & Scutellonema & Helycotylenchus & Trychodorus & Total \\
\hline & & Groundnut-sorghum & $5 \mathrm{c}$ & $130 \mathrm{c}$ & $97 \mathrm{c}$ & $62 \mathrm{~b}$ & $158 \mathrm{c}$ \\
\hline & 30 & Cowpea-sorghum & $157 \mathrm{ab}$ & $1138 \mathrm{ab}$ & 3157 a & 55 bc & $3212 \mathrm{a}$ \\
\hline & & Sorghum-sorghum & $175 \mathrm{a}$ & $1228 \mathrm{a}$ & $843 \mathrm{~b}$ & $377 \mathrm{a}$ & $1220 \mathrm{~b}$ \\
\hline & & Groundnut-sorghum & $53 \mathrm{c}$ & $135 \mathrm{c}$ & $510 \mathrm{c}$ & 207 & $905 \mathrm{c}$ \\
\hline & 90 & Cowpea-sorghum & $518 \mathrm{a}$ & $1213 \mathrm{a}$ & 3532 a & 618 & $5880 \mathrm{a}$ \\
\hline & & Sorghum-sorghum & $407 \mathrm{ab}$ & $940 \mathrm{ab}$ & $1892 \mathrm{~b}$ & 122 & $3360 \mathrm{~b}$ \\
\hline \multirow{6}{*}{$\begin{array}{l}\text { Nematodes in } \\
\text { sorghum roots }\end{array}$} & & Groundnut-sorghum & $8 \mathrm{c}$ & $4 \mathrm{c}$ & 0 & 0 & $12 \mathrm{c}$ \\
\hline & 30 & Cowpea-sorghum & 389 a & $60 \mathrm{ab}$ & 0 & 0 & 449 a \\
\hline & & Sorghum-sorghum & $160 \mathrm{ab}$ & $72 \mathrm{a}$ & 0 & 0 & $232 \mathrm{ab}$ \\
\hline & & Groundnut-sorghum & $4 \mathrm{c}$ & 0 & 0 & 0 & $4 \mathrm{c}$ \\
\hline & 90 & Cowpea-sorghum & $109 \mathrm{a}$ & 0 & 0 & 0 & $109 \mathrm{a}$ \\
\hline & & Sorghum-sorghum & $69 \mathrm{ab}$ & 0 & 0 & 0 & $69 \mathrm{ab}$ \\
\hline
\end{tabular}

Values affected by the same letter in the same column are not significantly different at $\mathrm{p}<0.05$, according to Fisher's test

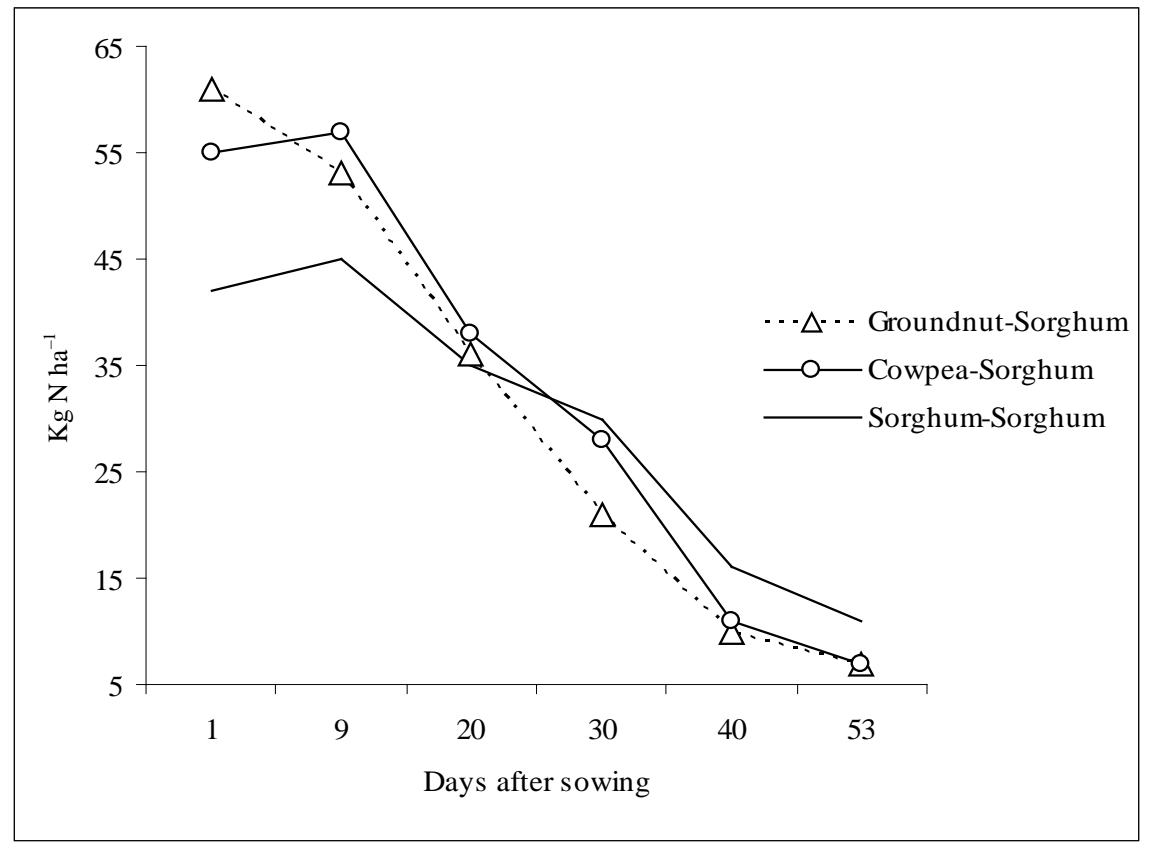

Figure 1. Effects of monocropping of sorghum, cowpea-sorghum and groundnut-sorghum rotations on soil mineral $\mathrm{N}$ during the 53 days after sowing in year 2001.

of rotations were evaluated over the next four years (2001-2004). Sorghum grain yields were affected ( $\mathrm{p}<$ 0.001 ) by fertilizer applications, crop rotations and years (Figures 2 and 3). However, interactions were not observed between rotations and fertilizers, indicating that previous legumes (rotations) affected sorghum yields whether fertilizers are applied or not, and conversely. Interaction was not observed between year and fertilizer, showing good responses to fertilizer whatever the rainfall in a given season.

During the first year, sorghum produced high yields even when fertilizers were not applied while yields were very low during the final two years (Figure 2). This can be explained by the positive effects of the previous fal- low in the first year of cultivation and the subsequent nutrient decrease. In the absence of fertilizer, soil nutrients are exported, leading to declining fertility and yield decrease during the next four years [9]. Chemical NPK fertilisation alone increased sorghum grain yields in the presence of this low soil fertility, thereby indicating good response to chemical fertilizer $[1,9,10]$. Application of chemical NPK fertilizer associated with manure produced the highest yields during the five years of this experiment. Similar results relating to the beneficial effects of chemical and organic fertilizers on crop yields have been reported, although they are usually attributed to the role of organic materials both in correcting soil acidity and acting as a source of nutrients $[1,9,11]$. 


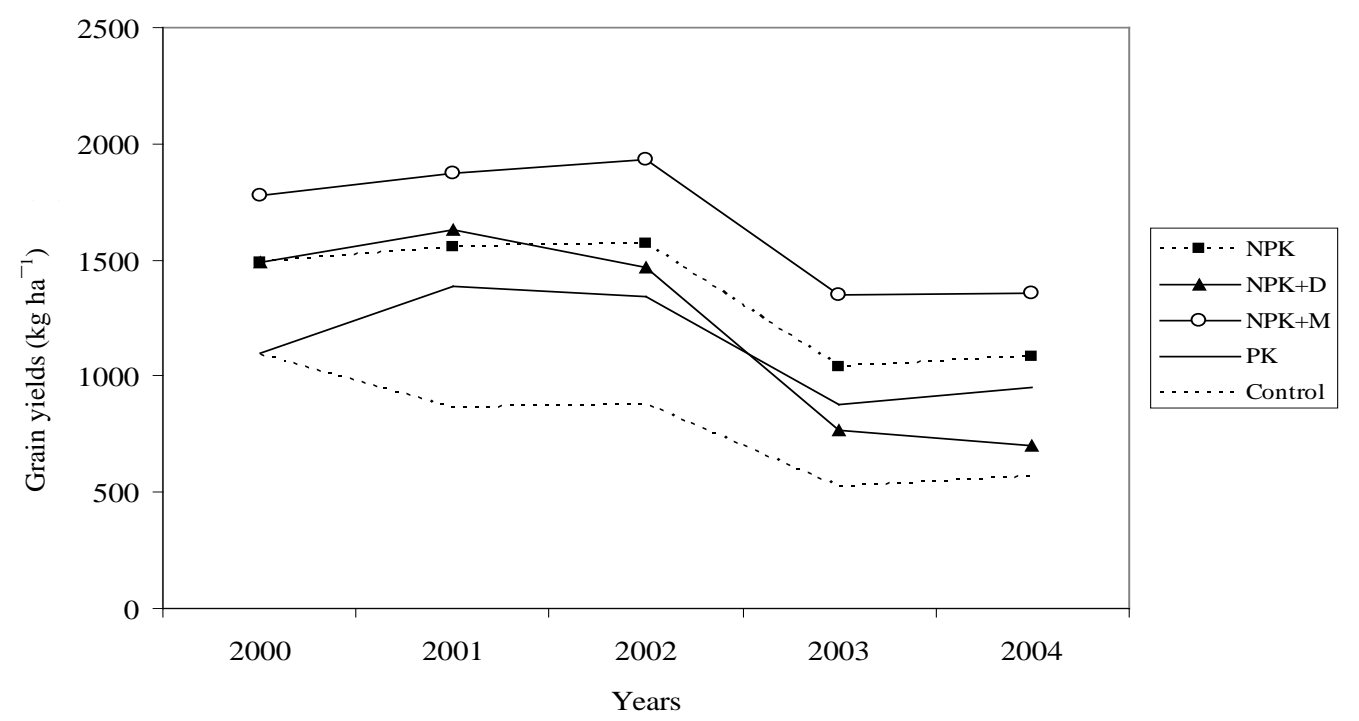

Figure 2. Effect of fertilizer applications on three rotations (cowpea-sorghum, groundnut-sorghum and sorghum-sorghum) on sorghum grain yields during four years (2001-2004).
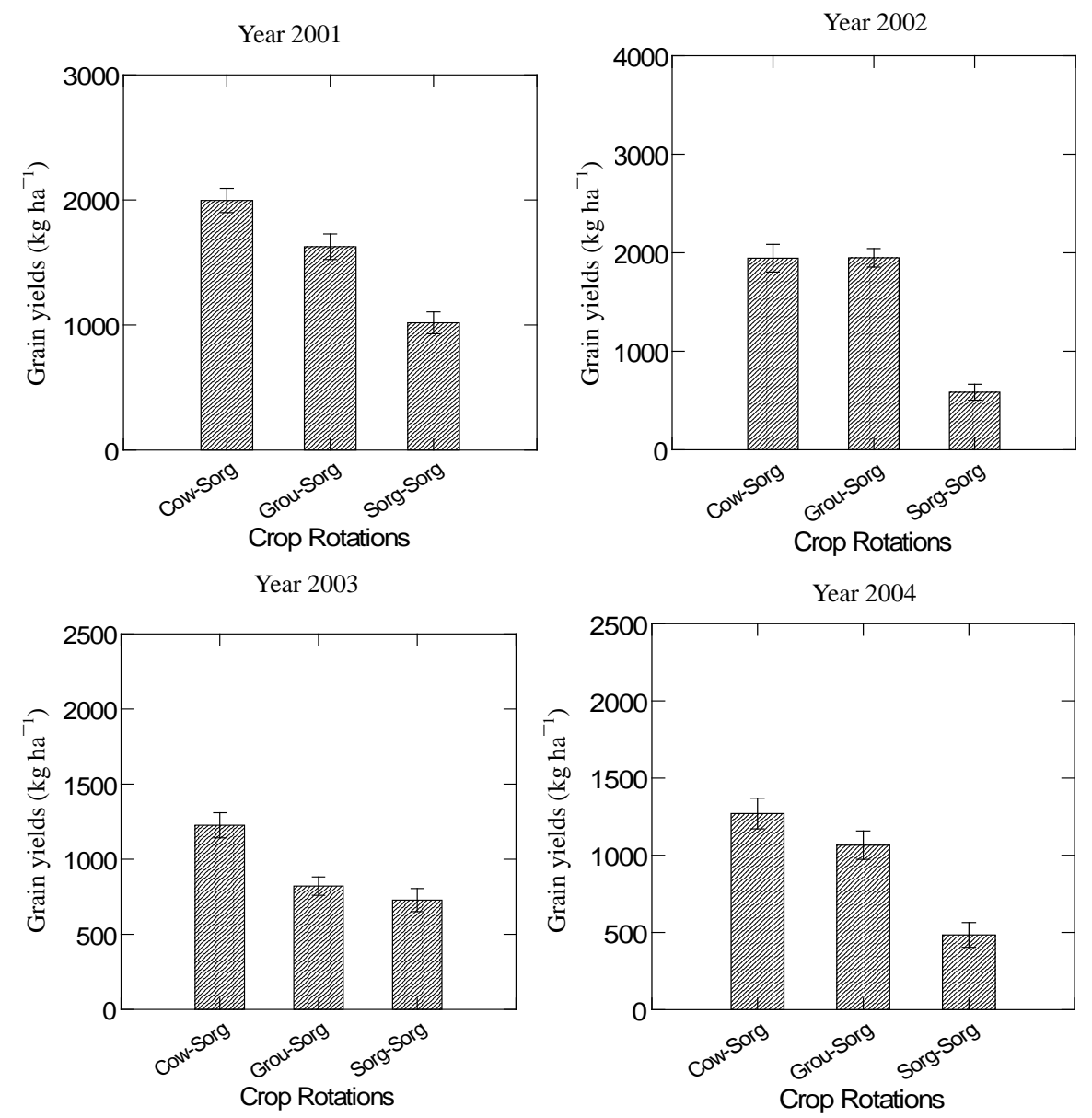

Figure 3. Effect of monocropping of sorghum and rotations with legumes (groundnut-sorghum and cowpea-sorghum) on sorghum grain yields during four years (2001-2004). Cow-Sorg = cowpea-sorghum; Grou-Sorg = groundnut-sorghum; Sorg-Sorg = sorghum-sorghum. 
An interaction was only observed between years and rotation. The distribution of rainfall seemed to be more important than the quantity of water received during the season. For example, the highest grain yields were obtained in 2001 and 2002 when there was good distribution of rains, particularly in September and August, even though the total rainfall was lowest of the five years of the experiment.

Mono cropping of sorghum produced the lowest yields during the four years, and rotation of sorghum with legumes increased sorghum yields by from $50 \%$ to $300 \%$ compared to monocropping (Figure 3). The effects of legumes were particularly noticeable during the first year of rotation (2001). Sorghum grain yields increased from 0.9 tonnes $\mathrm{ha}^{-1}$ in monocropping of sorghum to 1.7 and 2.0 tonnes $\mathrm{ha}^{-1}$ when sorghum was rotated with groundnut and cowpea, respectively. Except for one year (2002), sorghum yields were higher in cowpea-sorghum than a groundnut-sorghum rotation.

\section{DISCUSSION}

The two legumes increased soil mineral $\mathrm{N}$ during the first weeks of the cropping season. Legume residues provided more organic $\mathrm{N}$, a source of mineral $\mathrm{N}$ for the succeeding crop [12]. Despite the exportation of legume shoots, the remaining crop residues and the below ground part of legumes can improve organic matter of the topsoil. Compared to sorghum, the residues of legumes are of better quality. As shown by soil mineral $\mathrm{N}$, they better contributed to supplying more $\mathrm{N}$ in legume-sorghum rotations. Giller et al. [13] estimated that $15 \%$ to $20 \%$ of the nitrogen of legumes is recycled for the succeeding crop by legume residues. The positive interaction between organic and mineral $\mathrm{N}$ can justify the effectiveness of legume on $\mathrm{N}$ uptake by sorghum.

Our data confirmed the differences between the two legumes on soil and roots infestation by nematodes. As observed by other studies, cowpea increased nematode infestation [14], while groundnut decreased the population of nematodes $[3,15,16]$. The biological effects of legumes are complex [17] but our results showed that the N-effect seemed to be the most important factor governing sorghum response to crop rotation. Nitrogen and $\mathrm{P}$ are known to be the most limiting factors of $\mathrm{Al}-$ fisols and Ultisols of West Africa [1,5]. Legumes can also improve other soil properties such aspH of acid soils, microbial $\mathrm{N}$ and fungal biomass in the rhizosphere [17]. In the sensitive rainfed ecosystem of West Africa, the mineral $\mathrm{N}$ supplied by legume residues at the start of the season as a basal source of $\mathrm{N}$ can explain the good development and yields of sorghum. The good soil conditions created by legume residues such as cowpea can assist the development of nematodes. The infestation by nematodes was lowest in a groundnut-sorghum rotation, probably because groundnut is not a favourable host for nematodes of sorghum [3]. Despite high infestation (cowpea) or reduction in nematode population (groundnut), nematodes didn't affect sorghum yields and no relationship was observed between sorghum yields and nematode densities in soil or sorghum roots. The better growth of sorghum in legume-sorghum rotations dominated or limited the effects of nematodes. The quantity and quality (organic $\mathrm{N}$ ) supplied by the residues of legumes improve soil $\mathrm{N}$, biological properties and availability of other nutrients, leading to better growth and good health for the succeeding sorghum. As reported inprevious work, subsequent cereal yields are usually increased in legume-cereal rotations $[3,4,18]$ as a consequence of mineral $\mathrm{N}$ provided by mineralization of legume residues [19-22] and the improvement of soil biological properties and availability of nutrients [17]. Then, despite the increase of the population of nematodes, the succeeding sorghum benefits from good nutriational conditions and has quicker and better growth, particularly during the first period of the season. Otherwise, the highest yields in cowpea-sorghum rotations explained the predominance of $\mathrm{N}$-effect on the negative effects of parasitic nematodes.

\section{CONCLUSIONS}

Compared to the monocropping of sorghum, the two legumes (cowpea and groundnut) increased $\mathrm{N}$ uptake by succeeding sorghum as a consequence of organic $\mathrm{N}$ supplied by legume residues (fallen senescent leaves and below ground parts). Groundnut remains the most effective legume for reducing nematode infestation. Cowpea, on the other hand, increased nematode infestation, but because of the predominance of the $\mathrm{N}$-effect of legume residues and the improvement in physical, chemical and biological conditions of the soil by legume residues, nematode infestation did not affect the productivity of the succeeding sorghum.

\section{ACKNOWLEDGEMENTS}

This study was partly funded by the International Atomic Energy Agency (IAEA) under IAEA Contract BKF-10952. This research was conducted as part of FAO/IAEA Coordinated Research Project on Tropical Acid Soils. The authors are grateful to IAEA, FAO/IAEA division and Dr. F. Zapata, Project Officer for his assistance.

\section{REFERENCES}

[1] Bationo, A. and Mokwunye, A.U. (1991) Alleviating soil fertility constraints to increased crop production in West Africa: The experience of the Sahel. In: Mokwunye, A.U. Ed., Alleviating Soil Fertility Constraints to Increased 
Crop Production in West Africa, Kluwer Academic Publishers, Dordrecht, 195-215.

[2] Stoorvogel, J.J. and Smaling, E. (1990) Assessment of soil nutrient depletion in sub-Saharan Africa, 1983-2000. Main Report 28, DLO The Winang Staring Centre for Integrated Land, Soil and Water Research (SC-DLO), Wageningen, 1, 137.

[3] Bagayoko, M., Buerkert, A., Lung, G., Bationo, A. and Römheld, V. (2000) Cereal/legume rotation effects on cereal growth in Sudano-Sahelian West Africa: Soil mineral nitrogen, mycorrhizae and nematodes. Plant Soil, 218, 103-116. doi:10.1023/A:1014957605852

[4] Bationo, A. and Ntare, B.R. (2000) Rotation and nitrogen fertilizer effects on pearl millet, cowpea and groundnut yield and soil chemical properties in a sandy soil in the semi-arid tropics, West Africa. Journal of Agricultural Science, 134, pp. 277-284. doi:10.1017/S0021859699007650

[5] Bado, B.V., Bationo, A. and Cescas, M.P. (2006) Assessment of cowpea and groundnut contributions to soil fertility and succeeding sorghum yields in the Guinean savannah zone of Burkina Faso (West Africa). Biology and Fertility Soils, 43, 171-176. doi:10.1007/s00374-006-0076-7

[6] Keeney, D.R. (1982) Nitrogen availability indices. In: Page, A.L., Millet, R.H. and Keeney, D.R., Eds., Methods of Soil Analysis. Part II, 2nd Edition, Agronomy Monograph. Madison, American Society of Agronomy, 9, 711-730.

[7] Seinhorst, J.W. (1962) Modifications of the elutriation method for extracting nematodes from soils. Nematologica, 8, 117-128.

[8] Steel, R.D.G. and Torrie, J.H. (1980) Principles and procedures of statistics: A biometrical approach. The McGraw-Hill Companies, New York.

[9] Bado, B.V., Sedogo, M.P., Cescas, M.P. and Lompo, F. (1997) Effet à long terme des fumures sur le sol et les rendements du mais au Burkina Faso. Cahiers Agricultures, 6, 571-575.

[10] Berger, M., Belem, P.C., Dakouo, D. and Hien, V. (1987) Le maintien de la fertilité des sols dans l'Ouest du Burkina Faso et la nécessité de l'association agriculture-élévage. Coton et Fibres Tropicales, XLIIFasc 3, 10-14.

[11] Pichot, J., Sédogo, M.P. and Poulain, J.F. (1981) Évolution de la fertilité d'un sol ferrugineux tropical sous l'influence des fumures minérales et organiques. Agronomie Tropicale, 36, 122-133.
[12] Varvel, G.E. and Peterson, T.A. (1990) Nitrogen fertilizer recovery by corn in monoculture and rotation systems. Agronomy Journal, 82, 935-938. doi:10.2134/agronj1990.00021962008200050019x

[13] Giller, K.E., Mcdonagh, J.F., Toomsan, B., Limpi-nuntana, H.F, Cook, H.C. and Lee, H. (1995) Legumes in the cropping systems of North-East Thailand. Proceedings of the 3rd International Conference on Sustainable Agriculture, University of London, Wye College Press, Ashford.

[14] Riekert, H.F. and Henshaw, G.E. (1998) Effect of soybean, cowpea and groundnut rotations on root-knot nematode build-up and infestation of dry-land maize. African Crop Science Journal, 6, 377-383.

[15] Diop, M.T., Ndiaye, S., Mounpotr, S. and Mateille, D.T. (2000) Développement des populations de Meloidogynejavanica et de Scutellonemacavenessis dans les systèmes de cultures maraîchères au Sénégal. Nematology, 5, 535-540.

[16] Alvey, S., Bagayoko, M., Neuman, G. and Buerkert, A. (2001) Cereal/legume rotations affect chemical properties and biological activities in two West African soils. Plant Soil, 231, 45-54. doi:10.1023/A:1010386800937

[17] Marschner, P., Joergensen, R.G., Piepho, H.P. and Buerkert, A. (2004) Legume rotation effects on early growth and rhizosphere microbiology of sorghum in West African soils. Plant and Soil, 264, 1-2. doi:10.1023/B:PLSO.0000047767.62179.25

[18] Peoples, M.B. and Crasswell, E.T. (1992) Biological nitrogen fixation: Investment, expectation and actual contribution to agriculture. Plant Soil, 141, 13-39. doi:10.1007/BF00011308

[19] Shumba, E.M. (1990) Response of maize in rotation with cowpea to NPK fertilizer in a low rainfall area. Zimbabwe Journal of Agricultural Research, 28, 39-45.

[20] Wani, S.P., Rupela, O.P. and Lee, K.K. (1995) Sustainable agriculture in the semi-arid tropics through biological nitrogen fixation in grain legumes. Plant Soil, 174, 29-49. doi:10.1007/BF00032240

[21] Chalk, P.M. (1998) Dynamics of biologically fixed $\mathrm{N}$ in legume-cereal rotations: A review. Australian Journal of Agricultural Research, 49, 303-316. doi:10.1071/A97013

[22] Franzluebbers-Kathrin, K.Z., Juo-Anthony, S.R. and Hossner-Lloyd, R. (2000) Tillage, crop residue, legume rotation and green manure effects on sorghum and millet yields in the semiarid tropics of Mali. Plant Soil, 225, 141-151. doi:10.1023/A:1026589528352 